\title{
FACTORS RELATING TO KNOWLEDGE ABOUT GASTRITICAL SWAMEDCATION AMONG STUDENTS AT PONDOK HIDAYATUSSALIKIN PANGKALPINANG
}

\author{
Rachmawati Felani Djuria
}

School of Health Polytechnics, Ministry of Health Pangkalpinang

\begin{abstract}
Background: Gastritis was one of the diseases that could be self-treatment handling. Usually gastritis was found middle age in many of student. This is because the student choose a task that many lectures and activites on school, not yet eat. One of the school in Pangkalpinang is Pondok Pesantren Hidayatussalikin. The purposes of this study is to know the factors that related to knowledge about self-treatment gastritis at Pondok Pesantren Hidayatussalikin Pangkalpinang.

Subjects and Method: This was a cross-sectional study conducted at Pondok Pesantren Hidayatussalikin Pangkalpinang. A total of 130 students were enrolled in this study. The dependent variable was knowledge about self-treatment gastritis. The independen variables were interest, experience, and information resources.

Results: 125 students had knowledge about self-treatment gastritis self-treatment gastritis (96.3\%), 95 students (73.6\%) had gastritis, and 69 students (53.6\%) got information about self-treatment gastritis from one dan two media. 88 respondents (67.7\%) had good level of knowledge about self-treatment gastritis. There was no statistically significant relationship between interest, experience, and information resources on the level of knowledge about self-treatment gastritis

Conclusion: Knowledge about self-treatment gastritis is not associate by interest, experience, and information resources.
\end{abstract}

Keywords: self-treatment gastritis, knowledge, interest, experience, information resource

\section{Correspondence:}

Rachmawati Felani Djuria. School of Health Polytechnics, Ministry of Health, Pangkalpinang. Jl. Telaga Biru I, Desa Padang Baru, Kecamatan Pangkalan Baru, Bangka Tengah, Bangka Belitung Province. Email: felanDJ87@gmail.com. Mobile: 081995596959.

The $7^{\text {th }}$ International Conference on Public Health

Solo, Indonesia, November 18-19, 2020 | 116 https://doi.org/10.26911/the7thicph.02.05 